\title{
Partner preference in the legume-rhizobia symbiosis and impact on legume inoculation strategies
}

\section{Stephane Boivin and Marc Lepetit*}

Laboratoire des Symbioses Tropicales et Méditerranéennes, INRA, Montpellier, France

*Corresponding author: E-mail: marc.lepetit@inra.fr

\section{Contents}

1. Introduction

2. Early partner choice in the legume-rhizobium symbiosis 326

2.1 Legume and rhizobial symbiotic mechanisms controlling the AFN 326

2.1.1 Symbiosis initiation by the perception of legume plant flavonoid spectra 326

2.1.2 Rhizobial AFN is generally determined by the range of secreted NFs 327

2.1.3 The genetic diversity of legume LySM-RLK receptors impacts rhizobial AFN 329

2.1.4 AFN can depend on the secretion of bacterial effectors 330

2.2 Competitiveness to form root nodules (CFN) is a determinant of early partner 331 choice in rhizobial populations

3. Post-infection partner preference in the legume-rhizobium symbiosis

3.1 Integration of legume-rhizobium interactions at the whole plant level 332

3.2 Control of the symbiosis by local N availability 334

3.3 Control of symbiosis by the whole plant N demand 335

3.4 Differential allocation of C metabolites by the plant to the nodules 337

4. Conclusions 338

References $\quad 340$

\begin{abstract}
Legumes interact with diverse soil bacteria of the genus Rhizobium to form dinitrogen $\left(\mathrm{N}_{2}\right.$ )-fixing symbiotic root nodules. This symbiotic interaction occurs under plant nitrogen (N)-deficit and only between compatible partners. When young nodules are formed, bacteroids begin to fix atmospheric $\mathrm{N}_{2}$ and provide ammonium to the plant which in return provides phytosynthates to the bacteria. Ability and Competitiveness to Form root Nodules (AFN and CFN) within natural populations have a strong impact on early partner choice. In soil, there are frequently multiple compatible partners and legume roots are often colonized by multiple rhizobia displaying different Symbiotic $\mathrm{N}_{2}$ Fixation (SNF) efficiencies. In mature nodules, Post-Infection Partner Preference (PIPP)
\end{abstract}


shape partner choice by favoring effective symbiotic $\mathrm{N}_{2}$ fixing structures to the expense of inefficient ones. Little is known about mechanisms involved in legume-rhizobium partner choices despite the relevance of this trait to design new strategies to improve inoculation of legume crops.

\section{Introduction}

Legumes have the unique ability to associate with rhizobia within specific symbiotic root organs, called nodules. The legume-rhizobium symbiosis has the emerging property to use dinitrogen $\left(\mathrm{N}_{2}\right)$ present in the air as an unlimited nitrogen $(\mathrm{N})$ source and therefore to circumvent a soil mineral $\mathrm{N}$ limitation. Atmospheric $\mathrm{N}_{2}$ fixation takes place within bacteroids where it is transformed into ammonium and translocated to the legume host roots. In return, the plant provides photosynthates to the bacteria (Oldroyd, Murray, Poole, \& Downie, 2011). Legume-rhizobium interactions are however not ubiquitous as these symbioses happen only between compatible partners.

In soil and rhizosphere, bacteria form complex populations which composition vary depending on environmental conditions (Fierer \& Jackson, 2006; Kaiser et al., 2016; Rousk et al., 2010). Rhizobia represent a little part of soil bacteria $(<1 \%)$ but high local variations in population size and symbiotic performances are often observed (Wakelin et al., 2018). Although different protocols were designed to study rhizobia populations from soil samples, their identification and direct quantification remain difficult, mainly because of their low density in soils combined with quality issues of the DNA extracted from soil samples (Laguerre, Bardin, \& Amarger, 1993; Sullivan, Eardly, van Berkum, \& Ronson, 1996; Zézé, Mutch, \& Young, 2001). Taking advantage of their capacity to associate with plants within nodules, rhizobia have been mostly collected from root nodules, which were considered to be generally occupied by a dominant rhizobium genotype (Bourion et al., 2018; Laguerre et al., 2012). This so-called "trapping" strategy coupled with molecular methods allowed drawing indirect pictures of the rhizobia diversity in soils (Kumar et al., 2015; Laguerre, Allard, Revoy, \& Amarger, 1994; Young \& Wexler, 1988). Indeed, legume-rhizobium partner choice mechanisms biased the diversity assessment. Although a large genetic diversity is frequently found at a local scale in soils (Bailly et al., 2011; Kumar et al., 2015), some rhizobia are occasionally absent, and therefore some specific legume hosts cannot be nodulated in these soils. For example, soybean is native from East Asia where its symbionts 
are naturally found in soils, but the compatible bacteria Bradyrhizobium japonicum are not indigenous in western Europe and inoculation is then required (Revellin, Pinochet, Beauclair, \& Catroux, 1996).

The partner choice influences the symbiotic interaction from early steps, i.e. in relation with the infection of the plant by symbiotic bacteria, as well as later steps, i.e. in $\mathrm{N}_{2}$ fixing nodules. The intrinsic Ability to Form root Nodules (AFN) is generally estimated as the capacity to form nodules with a legume in mono-inoculation experiments. As the host spectrum of some rhizobia is larger than for others, AFN specificities are then observed at various phylogenetic levels, from specific rhizobium genotypes to different rhizobium complex species. However, rhizobia in a given soil potentially share an equivalent AFN, but display a wide range of Competitiveness to Form root Nodules (CFN) with their compatible host plants. This CFN is estimated as the capacity of a specific genotype to form nodules when multiple different compatible partners co-exist. Therefore, not only AFN but also CFN determine the early partner choice (Amarger, 1981; Triplett \& Sadowsky, 1992). Once young nodules are formed after the selection of both compatible and competitive rhizobium genotypes, the Symbiotic $\mathrm{N}_{2}$ Fixation (SNF) begins progressively. The SNF efficiency of individual bacteria strongly varies within rhizobial populations, as well as in function of the legume host and of environmental conditions. Because CFN and SNF efficiency are genetically independent, young nodules with different levels of SNF efficiency are formed on the same host root system (Bourion et al., 2018). Consequently, a mosaic of symbiotic nodule organs, displaying various levels of efficiency, is frequently observed in natural conditions on legume root systems (Laguerre, Louvrier, Allard, \& Amarger, 2003; Mutch \& Young, 2004). At this stage, Post-Infection Partner Preference (PIPP) mechanisms influence both the dynamic of the interaction and nodule development, in order to (1) satisfy the plant $\mathrm{N}$ demand and (2) prevent dissipation of carbon (C) metabolites toward inefficient symbiotic structures. Understanding genetic and molecular bases of AFN, CFN and PIPP is therefore highly relevant to select the best symbiotic partners, design inoculation strategies, and predict their benefits for agro-ecological systems.

This chapter reviews our current knowledge on symbiotic partner choices in conditions where multiple symbiotic partners can interact with their host plants. The first part focuses on the early partner choice and describes mechanisms modulating the initiation of the legume-rhizobium symbiotic interaction (i.e. AFN and CFN). The second part focuses on PIPP that occurs later in nodules when legume hosts are associated with multiple 
partners. Mechanisms related to SNF efficiency and plant $\mathrm{N}$ signaling, potentially involved in PIPP, are additionally presented. To conclude, consequences of partner choice for the improvement of inoculation strategies in legume crops is discussed.

\section{Early partner choice in the legume-rhizobium symbiosis}

\subsection{Legume and rhizobial symbiotic mechanisms controlling the AFN}

\subsubsection{Symbiosis initiation by the perception of legume plant flavonoid spectra}

Under $\mathrm{N}$ deficit, legumes associate with compatible rhizobia, and the Ability to Form root Nodules (AFN) mainly depends on two conditions: the capacity of rhizobia to detect plant signals (i.e. flavonoids) and in return, the capacity of legume plants to recognize Nod Factors (NFs) and bacterial surface polysaccharides (SPs; Fig. 1; Oldroyd et al., 2011). Legume roots release a wide range of flavonoids in the rhizosphere. The amount and the chemical structure of secreted flavonoids impact bacterial symbiotic responses, as some chemical species are more effective than others to trigger responses on specific rhizobia (Jiménez-Guerrero et al., 2017; Maj, Wielbo, Marek-Kozaczuk, \& Skorupska, 2010). Synergy between the different types of flavonoids exsuded can modulate the symbiotic initiation (Begum, Leibovitch, Migner, \& Zhang, 2001; Firmin, Wilson, Rossen, \& Johnston, 1986). Flavonoids interact with the LyR transcriptional activator nodulation D (NodD) protein which binds to specific Nod Boxes (NBs) DNA motifs located upstream of a number of bacterial nodulation genes (nod genes) involved in the production, modification or transport of NFs (Hong, Burn, \& Johnston, 1987; Peck, Fisher, \& Long, 2006). The broad host-range Rhizobium sp. NGR234 strain possess two different nodD alleles, called NodD1 and NodD2, which potentially interact with 19 NBs (Fellay et al., 1998; Kobayashi, Naciri-Graven, Broughton, \& Perret, 2004), whereas the Rhizobium leguminosarum symbiovar viciae $(R l v)$ strain 3841 , which forms nodule only with plants of the Fabeae tribe, has only one NodD protein that potentially interact with 6 NBs (4 validated and 2 putatives; Young et al., 2006). Therefore, plasticity and diversity of flavonoids produced by the plant and their perception by rhizobia influence the AFN. Moreover, the regulation of nod gene expression and nodulation via NodD can be also affected by non-flavonoid compounds secreted by legumes (i.e. jasmonic acid, 


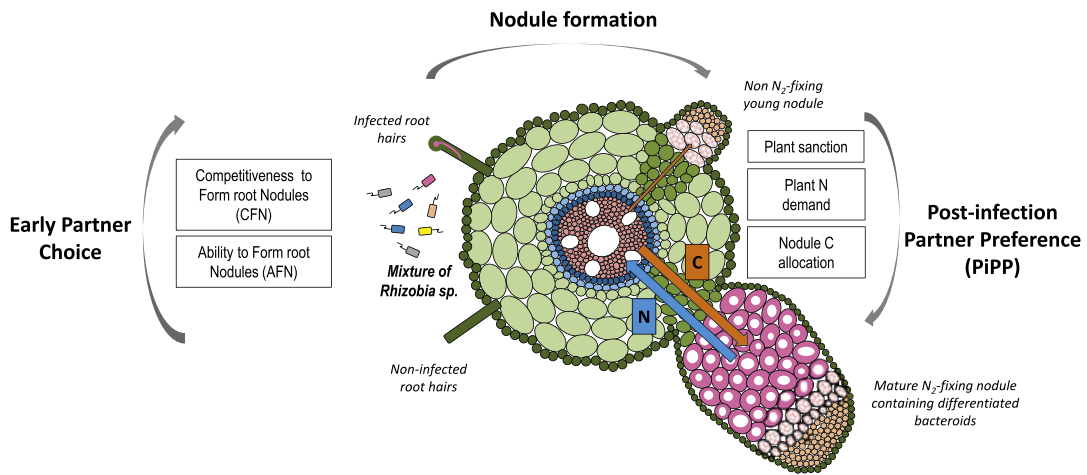

Fig. 1 Early partner choice and post-infection partner preference in the legume-rhizobium symbiosis in a context of multiple partners. The schematized transversal root section represents the main developmental steps of the legume-rhizobium symbiosis, from the root hairs infection to the $\mathrm{N}_{2}$ fixing nodule. Rhizobia in soils are diverse and display variable Abilities and Competitiveness to Form root Nodules (AFN and CFN), as well as variable capacities to drive efficient Symbiotic $\mathrm{N}_{2}$ Fixation (SNF). Nod factors, surface polysaccharides, and secretion systems from rhizobia, as well as flavonoids and LysM-RLKs from legume hosts, are the main factors modulating the early partner choice between symbiotic partners. Symbiosis initiation and nodule formation result in young nodules that are non $\mathrm{N}_{2}$ fixing and differentiate into expanded mature nodules with a large central zone containing $\mathrm{N}_{2}$ fixing bacteroids. In these nodules, large fluxes of nitrogen $(\mathrm{N})$ from the nodules to the plant roots and carbon $(\mathrm{C})$ phytosynthates from the plant to the nodules are exchanged. Evidences suggest that the local $\mathrm{N}_{2}$ fixation capacity, the whole plant $\mathrm{N}$ demand, and $\mathrm{C}$ allocation may pilot the proliferation of efficient $\mathrm{N}_{2}$-fixing nodules to the expenses of the inefficient ones, and are therefore potential drivers of Post-Infection Partner Preference (PIPP). Dark green: root hairs and epidermis; pale green: cortex; middle green: division of cortical cells; light blue: endodermis; dark blue: pericycle; pink, stele tissues including vascular bundles; orange: nodule meristem; pink points: nodule infection zone; pink circles: nodule $\mathrm{N}_{2}$ fixation zone; blue arrow: $\mathrm{N}$ flux; orange arrow: $C$ flux. Different rhizobium genotypes are represented with different colors.

stachydrine, trigonelline, tetronic and erythronic acids) and non-legume plants (i.e. vanillin and isovanillin), suggesting that a large set of plantsecreted molecules can influence the bacterial NodD function (Gagnon \& Ibrahim, 1998; Le Strange, Bender, Djordjevic, Rolfe, \& Redmond, 1990; Sun et al., 2006).

\subsubsection{Rhizobial AFN is generally determined by the range of secreted NFs}

The best characterized genes regulated by flavonoids and NodD are nod genes, grouped together in clusters generally located on a symbiotic plasmid 
or in specific mobile islands of the chromosome (Kaneko et al., 2002; Kondorosi, Banfalvi, \& Kondorosi, 1984; Young et al., 2006). The typical set of nod genes include conserved core genes and additional genes specific to some rhizobia (Mergaert, Montagu, \& Holsters, 1997; Triplett \& Sadowsky, 1992). In $R l v$, the nod gene cluster contains the nodD, nodO genes, and the $\operatorname{nod} A B C I J(X)$, nodFEL, nodMN(T) operons. These transcriptional units are under the control of 4 NBs (Spaink, Okker, Wijffelman, Pees, \& Lugtenberg, 1987). The nodABC, nodFEL and nodMN operons are responsible of the biosynthesis of lipo-chitooligosaccharidic NF molecules that are composed of four to five $\mathrm{N}$-acetyl glucosamines (forming the NF sugar backbone) and a terminal $\mathrm{N}$-acylated sugar carrying a fatty acid chain of 16-18 C residues (Mergaert et al., 1997). Different species of rhizobia produce different NFs characterized by various chemical substitutions (i.e. acetyl, carbamoyl, sulfate, fucosyl, arabinosyl and methyl residues) on the sugar backbone, and by different unsaturation levels of the acyl chain (Cooper, 2004). Specific nod genes are involved in these modifications and hence, depending on strains and species, this allows modulating the rhizobial AFN with compatible legumes. For example, some $R l v$ strains are able to specifically interact with the Pisum sativum cultivar 'Afghanistan' because they produce a specific NF resulting of the nodX gene function (Firmin, Wilson, Carlson, Davies, \& Downie, 1993). As NFs are important factors in the legume-rhizobium symbiotic initiation, their secretion in the extracellular medium is a key step for legume NF perception and is mediated by the transmembrane proteins NodI and NodJ (Spaink et al., 1995). Some genes are present in the nod gene cluster of certain rhizobia, such as nodT and nod $O$ in $R$. leguminosarum (Rivilla, Sutton, \& Downie, 1995; Surin, Watson, Hamilton, Economou, \& Downie, 1990). These two genes are involved in the secretion of NFs as well as in the modulation of the host-specificity and AFN (Djordjevic, Schofield, \& Rolfe, 1985; Lewis-Henderson \& Djordjevic, 1991).

The AFN with compatible legumes (generally defined as "symbiovars") is generally well-correlated with the nod gene phylogenetic diversity, but very poorly with the whole chromosome genetic variation (Kumar et al., 2015). Consequently, closely-related chromosome backgrounds can be found in different "symbiovars". Symbiovars are well discriminated by their nod genes present on plasmids or on mobile islands. Because nod genes are generally located on symbiotic plasmids, horizontal gene transfer (HGT) is one of the main drivers of AFN genetic evolution in populations. One example illustrating the impact of HGTs on AFN has been evidenced in 
New Zealand where Rhizobium loti is absent in most of uncultivated soils (Patrick \& Lowther, 1992). A strain of R. loti, which is able to nodulate Lotus corniculatus, was introduced in a field and root nodule trapping was performed seven years later at the same place (Sullivan, Patrick, Lowther, Scott, \& Ronson, 1995). Molecular genotyping revealed the transfer of symbiotic genes from the introduced strain to native non-symbiotic rhizobia already present in the soil. HGTs have been well studied in pure cultures and bioinformatic tools are now available to investigate them across various microbe genomes (Li et al., 2018; Soucy, Huang, \& Gogarten, 2015). However, HGTs can only happen between compatible bacteria, and mechanisms controlling gene exchanges within complex bacterial populations are not well understood (Klümper et al., 2015). The Quorum Sensing (QS) is a gene expression regulatory system acting at the level of bacterial populations (Papenfort \& Bassler, 2016). In R. leguminosarum, the transfer of the symbiotic plasmid carrying nod genes is mediated by LuxR-type QS regulators and therefore, the QS system is predicted to influence the diversity and the abundance of rhizobial genotypes in soil populations (McAnulla, Edwards, Sanchez-Contreras, Sawers, \& Downie, 2007).

\subsubsection{The genetic diversity of legume LysM-RLK receptors impacts rhizobial AFN}

Perception of NFs is mediated by plant receptors that trigger the first steps of rhizobial infection (Fig. 1). They belong to the large and diverse family of LysM receptor-like kinases (LysM-RLKs) (Gough, Cottret, Lefebvre, \& Bono, 2018), which possess several extracellular LysM domains that are able to bind NFs, a transmembrane domain, and an intracellular kinase domain which transduces the signal. In Medicago truncatula and Lotus japonicus model legumes, two different LysM-RLK co-receptors, likely forming dimers, have been identified (MtLYK3 and MtNFP, and LjNFR1 and LjNFR 5 respectively Dénarié, Debellé, \& Promé, 1996; Madsen et al., 2011; Radutoiu et al., 2007). The MtLYK3/LjNFR1 receptors belong to the "LysM domain-containing RLK" (LYK) family of proteins that have functional kinase domains, whereas MtNFP/LjNFR5 belong to the "LYK-related" (LYR) family of proteins that have lost an activation loop motif, leading to unfunctional kinase domains. Although a role in specific NF perception is yet demonstrated only for few LysM-RLKs, it is likely that polymorphism of these protein families has an important role for the variation and diversity of AFN. The ectopic expression of L. japonicus LjNFR 1 and LjNFR5 receptors in transgenic $M$. truncatula roots indeed 
allowed the formation of nodules by Mesorhizobium loti that is not a natural host of M. truncatula (Radutoiu et al., 2007). Evidences for a positive selection pressure on residues of the LysM domain of LYK3 have been shown, suggesting a role of LYK3 in controlling host specificity (Sulima et al., 2017). In the case of the specific interaction between the P. sativum cultivar 'Afghanistan' and the $R l v$ strain TOM, the pea sym2 allele, encoding a LysM-RLK, prevented the nodulation of European $R l v$ strains lacking the nodX gene (Davis et al., 1988; Firmin et al., 1993; Lie, 1984; Sulima et al., 2017). However, all symbiotic functions of LysM-RLKs may be not exclusively related to NFs and some SPs directly interact with LysM domains (Kawaharada et al., 2015). SPs are composed of extracellular polysaccharides (EPS), capsular polysaccharides (KPS) and lipopolysaccharides (LPS), and are implicated at various stages of the legume-rhizobium interaction, from root attachment to nodule colonization (for a review see Janczarek, Rachwał, Marzec, Grządziel, \& Palusińska-Szysz, 2015; Kelly, Radutoiu, \& Stougaard, 2017). The chemical structure of SPs, mainly composed of a mono or polysaccharide core unit decorated with various substitutions, can be variable and therefore may modulate the partner choice.

\subsubsection{AFN can depend on the secretion of bacterial effectors}

Bacterial effectors are released by secretion systems in the extracellular medium or directly inside plant root cells, and some of these are proposed to modulate the legume-rhizobium symbiosis (Costa et al., 2015; Miwa \& Okazaki, 2017). Until today, type I, III and VI secretion systems were involved in legume-rhizobium symbioses. The type I secretion system (T1SS), composed of transmembrane proteins such as PrsD and PrsE, can directly translocate proteins into the extracellular environment. This is the case for the $\mathrm{Ca}^{2+}$-binding protein NodO, as well as for glycanases and adhesins (Economou, Hamilton, Johnston, \& Downie, 1990; Russo et al., 2006). The type III secretion system (T3SS) is a complex of about twenty different proteins which form a syringe embedded in both bacterial and plant root host cell membranes (Miwa \& Okazaki, 2017; Staehelin \& Krishnan, 2015). The T3SS has been initially implicated in the secretion of bacterial effectors during plant pathogenic interactions (Miwa \& Okazaki, 2017; Staehelin \& Krishnan, 2015). T3SS effectors were identified in several rhizobial species like B. japonicum, B. elkani, S. fredii, but not in R. leguminosarum and Sinorhizobium meliloti. Proteins secreted via the T3SS in host root cells, which are called Nops for Nodulation outer proteins, influence the 
symbiosis establishment (Miwa \& Okazaki, 2017). NodD regulates the type III secretion system 1 (tts1) bacterial transcription factor that drives effector gene expression (Okazaki, Kaneko, Sato, \& Saeki, 2013). Interestingly, in B. japonicum, the two effectors NopE1 and NopE2 stimulate nodulation in soybean but repress it in mungbean (Krause, Doerfel, \& Göttfert, 2002), illustrating that T3SS can modulate the AFN. Some effectors are released through a type VI secretion system (T6SS), composed of membrane and tail complexes that translocate bacterial effectors into host cells, and which was initially linked to pathogenic bacteria effector secretion (for review see Costa et al., 2015). Despite the T6SS was suspected to inhibit the R. leguminosarum - pea symbiosis (Bernal, Llamas, \& Filloux, 2018) the specific contribution of such secreted effectors in Fabeae-rhizobium early partner choice remains to be demonstrated.

Some effectors released in legume host cells modulate plant immunity, illustrating that a crosstalk between immunity and early partner choice likely exist during nodulation (Gourion, Berrabah, Ratet, \& Stacey, 2015; Miwa \& Okazaki, 2017). A soybean R gene (rj2) was implicated in the decrease of AFN, suggesting that establishment of the root nodule symbiosis requires the evasion of plant immune responses triggered by rhizobial effectors (Yang, Tang, Gao, Krishnan, \& Zhu, 2010). Several evidences confirmed the role of secretion systems in the regulation of plant immune responses. The NopL and NopM T3SS-secreted proteins of the rhizobium NGR234 strain were indeed shown to suppress defense responses in N. benthamiana (Bartsev et al., 2004; Xin et al., 2012). In addition, T3SS-secreted effector proteins of the B. elkanii USDA61 bacterial strain were shown to highjack the NF-dependent pathway by suppressing plant defense responses in the soybean cultivar Clark-rj-1 (Okazaki et al., 2013).

\subsection{Competitiveness to form root nodules (CFN) is a determinant of early partner choice in rhizobial populations}

The capacity of a rhizobium to form nodules with a legume in mono-inoculation experiments does not necessarily predict the competitive success of the interaction in a context of multiple compatible partners (Fig. 1). Different rhizobia can share similar AFN but display a wide range of CFN in mixture, depending on the legume host (Bourion et al., 2018). Although $R l v$ are generally able to form nodules with pea or fababean when monoinoculated, these two plant species exposed to complex soil $R l v$ populations select preferentially different Rlv genotypes (Laguerre et al., 2003; Mutch \& 
Young, 2004). Preferential nodulation within compatible partners populations was also evidenced in the soybean-Bradyrhizobium symbiosis (Cregan, Keyser, \& Sadowsky, 1989; Keyser \& Cregan, 1987). More recently, a coinoculation of $R l v$ genotypes in mixture with a panel of pea accessions resulted in preferential symbiotic associations depending on pea genotypes (Bourion et al., 2018). Although the general concept of CFN has been described since several decades, very little is known about mechanisms controlling this process (Amarger, 1981; Triplett \& Sadowsky, 1992). The hypothesis of a differential proliferation of competitive bacterial genotypes in the host rhizosphere cannot be ruled out, but received little experimental support (Moawad, Ellis, \& Schmidt, 1984). In most rhizobia, a preferential association between the partner choice and the NF gene diversity supports the hypothesis that signaling pathways associated to early symbiont recognition are the major drivers of CFN (Kumar et al., 2015; Laguerre et al., 2003; Triplett \& Sadowsky, 1992). As described above, mechanisms controlling the symbiotic establishment can drastically differ among both host legumes and rhizobia genotypes (i.e. flavonoids, NFs, LysM-RLKs, SPs, TSSs) and may explain some variations in rhizobial CFN in natural populations. For instance, when the $R l v$ strain TOM is mixed with strains that do not express NodX and inoculated with the P. sativum cultivar 'Afghanistan' (nodulating only with the strain TOM), the NFs produced by the non-nodulating strain compete with NFs produce by TOM and drastically reduce its nodulation capacity (Dowling, Stanley, \& Broughton, 1989; Hogg, Davies, Wilson, Bisseling, \& Downie, 2002; Winarno \& Lie, 1979). In soil bacterial populations, NFs may be provided in trans between individuals, allowing bacteria unable to produce NFs by themselves to form nodules (Borthakur, Barker, Latchford, Rossen, \& Johnston, 1988). Other mechanisms such as antibiosis (antibiotics released in the extracellular medium by rhizobia and nonrhizobia) may also modulate the CFN (Triplett \& Barta, 1987; Robleto, Scupham, \& Triplett, 1997; for a review see; Naamala, Jaiswal, \& Dakora, 2016).

\section{Post-infection partner preference in the legume- rhizobium symbiosis}

\subsection{Integration of legume-rhizobium interactions at the whole plant level}

Symbiotic $\mathrm{N}_{2}$ Fixation (SNF) efficiency of the legume-rhizobium associations varies among bacteria able to infect legume roots and form 
nodules (Laguerre et al., 2012; Terpolilli, O’Hara, Tiwari, Dilworth, \& Howieson, 2008; Triplett \& Sadowsky, 1992). Moreover, a single strain may result in different levels of $\mathrm{N}$ acquisition when mono-inoculated on different compatible host legumes (Bourion et al., 2018; Kazmierczak et al., 2017). These different capacities depend on symbiotic partner couples as, for example, the $S$. meliloti strain RCR2011 was characterized as a poor $\mathrm{N}_{2}$ fixer in $M$. truncatula but as an efficient fixer in $M$. sativa (Terpolilli et al., 2008). As bacterial populations in the soil contain multiple competitive rhizobia, it is rather frequent that bacteria with different levels of $N_{2}$ fixation efficiency form nodules on roots (Laguerre et al., 2003; Mutch \& Young, 2004). Therefore, symbiotic legume root systems in soils are expected to be a mosaic of nodule organs with various level of SNF efficiency. However, the plant influences the dynamic of the interaction and activates Post-Infection Partner Preference (PIPP) mechanisms that favor the most efficient symbiotic organs to the expenses of the inefficient ones, in order to satisfy the plant $\mathrm{N}$ demand (Fig. 1).

Although plant $\mathrm{N}$ deficit is required to enable rhizobium-legume symbiosis (Streeter \& Wong, 1988), there is little evidence suggesting its role in early choices between various compatible symbiotic partners (Grillo, Stinchcombe, \& Heath, 2016). Indeed, the capacity of the legume-rhizobium association to fix $\mathrm{N}_{2}$ has little impact on partner choice until differentiation of the mature $\mathrm{N}_{2}$ fixing symbiotic organ occurs, and variations in early partner choice depend mainly on the capacities of bacteria to infect and colonize root cells rather than on whole plant $\mathrm{C}-\mathrm{N}$ trade-offs. Indeed, studies on M. truncatula/Sinorhizobium (Amarger, 1981; Laguerre et al., 2012) or pea/R. leguminosarum (Westhoek et al., 2017; Bourion et al., 2018) showed that inefficient $\mathrm{N}$ fixing bacteria genotypes, either corresponding to artificial mutants or natural isolates, can be as compatible and competitive as efficient $\mathrm{N}_{2}$ fixing bacteria, indicating that CFN is likely independent of SNF efficiency. Consequently, $\mathrm{N}_{2}$ fixing inefficient bacteria, so-called "cheaters", are frequently present in a fraction of the nodules of an host plant (Fujita, Aoki, \& Kawaguchi, 2014). In addition, mixtures of M. truncatula compatible rhizobia displaying different levels of SNF efficiency were inoculated on plants under contrasted $N$ regimes (Laguerre et al., 2012), revealing an effect of the $\mathrm{N}$ status of the plant on nodule numbers but not on CFN. The plant is therefore most probably unable to discriminate between inefficient and efficient bacteria as a function of its $\mathrm{N}$ demand before $\mathrm{N}_{2}$ fixation is indeed operating. However, as the mature symbiotic organs become efficient for $\mathrm{N}_{2}$ fixation, fluxes of $\mathrm{N}$ and $\mathrm{C}$ metabolites 
between the plant and the mature symbiotic organs impact significantly the whole plant growth and consequently its nutritional demand (Fig. 1). This then allows triggering plant $\mathrm{N}$ signaling mechanisms that modulate the symbiotic interaction and the partner preference. When a mixture of mature $\mathrm{N}_{2}$ fixing efficient and inefficient nodules is present within the same root system, the plant develop mechanisms stimulating the development of efficient structures to the expense of inefficient ones, in order to satisfy its $\mathrm{N}$ demand (Laguerre et al., 2012). It has been shown that regulation of plant nitrate acquisition is highly integrated at the whole plant level (for reviews see Bouguyon, Gojon, \& Nacry, 2012; Ruffel, Gojon, \& Lejay, 2014). The presence of nitrate induces both local and whole plant responses: nitrate stimulates locally root proliferation, nitrate uptake and nitrate assimilation whereas accumulation of downstream $\mathrm{N}$ metabolites by the whole plant triggers a systemic feedback repression of nitrate acquisition and root development when the $\mathrm{N}$ demand is satisfied. C metabolites accumulation also contributes to the regulation of nitrate acquisition: the level of photosynthates, translocated from shoots to roots, stimulates the root capacity to acquire nitrate (Lejay et al., 2003). It is well known from early studies that the addition of mineral $\mathrm{N}$ or of $\mathrm{N}$ metabolites strongly inhibits nodulation (Parsons, Stanforth, Raven, \& Sprent, 1993; Streeter \& Wong, 1988) but mechanisms adjusting symbiotic capacities to the nutritional demand of the legume plant are not well documented. However, several evidences argue that reminiscent mechanisms also exist in the case of SNF.

\subsection{Control of the symbiosis by local $\mathrm{N}$ availability}

Evidences for a local regulation of mature symbiotic organs by the efficiency of SNF have been reported. Suppressing $\mathrm{N}_{2}$ fixation by $\mathrm{Ar} / \mathrm{O}_{2}$ treatments result locally in a rapid inhibition of nodule growth (Kiers, Rousseau, West, \& Denison, 2003; Jeudy et al., 2010). It was proposed that the plant activates nodule autonomous mechanisms to locally restrict the development of nodules formed with ineffective bacteria (Kiers et al., 2003; Oono, Anderson, \& Denison, 2011). Long term $\mathrm{Ar} / \mathrm{O}_{2}$ treatments in determinate legumes resulted in a decrease of bacteroids fitness in nodules, associated with an early senescence (Kiers et al., 2003; Oono, Denison, \& Kiers, 2009). This result was interpreted as a "host sanction" toward the less beneficial partners. Indeed, in an evolutionary point of view, such sanction would tend to limit ineffective rhizobia multiplication and dispersion when they are released in the soil (Fig. 1). The concept has been extended to indeterminate nodules although bacteroids are, in this case, terminally 
differentiated and that only undifferentiated bacteria are able to multiply (Oono \& Denison, 2010; Oono et al., 2011). The general small size and the early developmental arrest of nodules formed by fix ${ }^{-}$mutant bacteria is globally in agreement with a concept that an absence of $\mathrm{N}_{2}$ fixation is associated to an inhibition of nodule development. Although reports in soybean/Bradyrhizobium and Medicago/Sinorhizobium symbioses indicate that mutations suppressing $\mathrm{N}_{2}$ fixation do not necessarily impact the reproductive fitness of rhizobia present in nodules (Laguerre et al., 2012; Marco et al., 2009), evidences for a long-term stimulation of the reproductive fitness of $\mathrm{fix}^{+}$Cupriavidus taiwanensis bacteria versus $\mathrm{fix}^{-}$bacteria in coinfected root systems of Mimosa pudica have also been reported (Daubech et al., 2017). Overall, these data demonstrate a control of symbiotic organ development by SNF efficiency. Mechanisms related to nodule oxygen permeability or $\mathrm{pH}$ have been additionally proposed to be instrumental in the local control of legume-rhizobium symbiotic organs by $\mathrm{N}$ signaling (Hunt \& Layzell, 1993; Kiers et al., 2003) but, up to date, mechanisms involved remain to be precisely elucidated.

\subsection{Control of symbiosis by the whole plant $\mathbf{N}$ demand}

Symbiotic organ development is also under the control of systemic signals integrated at the whole plant level. Nodule formation is inhibited by preexisting nodules through the autoregulation of nodulation (AON) pathway (review by Ferguson et al., 2019). A role of the $\mathrm{N}$ status of the plant in AON was suggested by the ability of several AON mutants to nodulate in the presence of high concentrations of nitrate that normally systemically inhibits nodulation in wild type plants. Conversely, a plant $\mathrm{N}$ deficit releases this repressive mechanism resulting in the stimulation of nodule formation (Jeudy et al., 2010). This contributes to the adjustment of nodule number to the $\mathrm{N}$ demand of the plant, and may explain the stimulation of nodulation frequently observed in plant mono-inoculated with poorly $\mathrm{N}_{2}$ fixing rhizobia (Bourion et al., 2018). Systemic regulations of mature symbiotic organs function and development by the whole plant $\mathrm{N}$ demand have been evidenced in $M$. truncatula using split root systems (Jeudy et al., 2010; Laguerre et al., 2012; Ruffel et al., 2008). The whole plant $\mathrm{N}$ satiety systemic signaling results in a rapid repression of the $\mathrm{N}_{2}$ fixation activity as well as in the initiation of nodule senescence. Whether this repression is the consequence of senescence or a direct modulation of the $\mathrm{N}_{2}$ fixation activity is not known. A change in permeability to oxygen within the nodule (so called the "oxygen barrier") has been also proposed (Hunt \& Layzell, 
1993), but whether this change is the consequence or the cause of the reduction of $\mathrm{N}_{2}$ fixation remains once more a matter of debate. A whole plant $\mathrm{N}$ deficit obtained either by $\mathrm{Ar} / \mathrm{O}_{2}$ treatments or by inoculation with fix ${ }^{-}$ mutant bacteria ( $\mathrm{fix}^{-}$roots) in a split-root experimental system triggers a compensatory response on the remaining $\mathrm{fix}^{+}$roots (Jeudy et al., 2010; Laguerre et al., 2012). It is firstly observed a systemic stimulation of nodule expansion, and secondly the formation of additional symbiotic organs (Jeudy et al., 2010; Laguerre et al., 2012). Whether this developmental response is associated to the upregulation of the specific $\mathrm{N}_{2}$ fixation activity (per gram of nodule) remains controversial (Laguerre et al., 2012; Ruffel et al., 2008; Sulieman \& Schulze, 2010). Systemic mechanisms adjusting the $\mathrm{N}_{2}$ fixation capacity to the symbiotic plant $\mathrm{N}$ demand are instrumental for the root nutrient "foraging", which is relevant to optimize plant growth in soil conditions that are intrinsically highly variable in time and space. These systemic regulations enable the plant to compensate a lower $\mathrm{N}_{2}$ fixation in the inefficient part of its symbiotic root system by stimulating the symbiotic development of the remaining beneficial roots. In contrast to the local regulation described above ("sanction"), this mechanism integrating the $\mathrm{N}_{2}$ fixation capacity to the plant $\mathrm{N}$ demand is likely to operate at the scale of the root bundle rather than at the scale of the individual nodule (Laguerre et al., 2012). A plant facing a uniform reduction of its symbiotic root capacity (e.g. having both fix + and fix-nodules uniformly distributed on its root system) is unable to triggers this systemic response probably because it is not possible to discriminate between efficient and inefficient root bundles and therefore to allocate resources preferentially to the efficient symbiotic roots (Laguerre et al., 2012).

Very little is known about the nature of systemic $\mathrm{N}$ signals (Parsons et al., 1993). As addition of amino acids in plant nutrient media generally rapidly represses $\mathrm{N}_{2}$ fixation, a pioneer hypothesis was that products of $\mathrm{N}$ assimilation, namely amino acid translocated through the phloem from shoots to roots, may act as mobile signals (Bacanamwo \& Harper, 1997; Sulieman, Fischinger, Gresshoff, \& Schulze, 2010; Sulieman \& Schulze, 2010). However, this hypothesis was never supported by a clear demonstration, as amino acids are also $\mathrm{N}$ sources rapidly assimilated and are able to trigger a repression of $\mathrm{N}_{2}$ fixation without inducing a direct signaling effect. Mechanisms behind the systemic regulation of symbiosis by $\mathrm{N}$ therefore remain mostly not known. AON is suggested to be implicated in the regulation of nodule formation by the $\mathrm{N}$ demand (Fig. 1; reviewed by Ferguson et al., 2019), as AON hypernodulating mutants are generally able to form nodules 
independently of the presence of a high level of mineral $\mathrm{N}$, as previously mentioned (Krusell et al., 2002; Olsson, Nakao, Bohlool, \& Gresshoff, 1989). However (1) $\mathrm{N}$ is not the only driver of $\mathrm{AON}$, as the $\mathrm{AON}$ pathway is activated far before the nodule becomes $\mathrm{N}_{2}$ fixing (Kosslak \& Bohlool, 1984; Kosslak, Bohlool, Dowdle, \& Sadowsky, 1983); and (2), the nodule expansion response to plant $\mathrm{N}$ deficit remains active in hypernodulating mutants, suggesting that additional AON-independent mechanisms are implicated (Jeudy et al., 2010; Kassaw, Bridges, \& Frugoli, 2015). Interestingly, another systemic mechanism acting in legumes in parallel of the classical AON pathway to positively regulate nodule formation was discovered recently (Huault et al., 2014; Laffont et al., 2019), but its function in symbiotic $\mathrm{N}$ signaling remain to be fully understood.

\subsection{Differential allocation of $\mathrm{C}$ metabolites by the plant to the nodules}

Symbiotic organs require large fluxes of $\mathrm{C}$ metabolites (namely sucrose and organic acids) translocated from photosynthetic shoots to nodules through the phloem. The main part of these $\mathrm{C}$ fluxes is required to fuel $\mathrm{N}_{2}$ fixation both as energy, as reducing power sources, and as $\mathrm{C}$ acceptors for ammonium assimilation (Oldroyd et al., 2011). C metabolites are also major resources required for root and nodule development (Fig. 1). Amino acids are products of $\mathrm{C}$ and $\mathrm{N}$ metabolisms that are tightly adjusted (Voisin, Salon, Jeudy, \& Warembourg, 2003). A high $\mathrm{CO}_{2}$ level increases photosynthesis and $\mathrm{C}$ metabolites production in the shoot, therefore enhancing $\mathrm{N}_{2}$ fixation in roots and the nodule biomass (Rogers et al., 2006; Rogers, Ainsworth, \& Leakey, 2009). As an elevation of $\mathrm{CO}_{2}$ is not generally associated to an increase of nitrate uptake from the soil, it was suggested that symbiotic $\mathrm{N}_{2}$ fixation will become more ecologically competitive compared to nitrate acquisition in a context of climate change associated to a strong increase of atmospheric $\mathrm{CO}_{2}$ concentrations (Rogers et al., 2009). It is generally assumed that the $\mathrm{C}$ provision to the nodule limits $\mathrm{N}_{2}$ fixation efficiency (Rogers et al., 2006). Variations of $\mathrm{N}_{2}$ fixation capacity of symbiotic associations may be associated to differences in the $\mathrm{C}$ use efficiency of bacteroids. For example, the activity of so-called the gamma-aminobutyric acid "shunt" of the bacteroid tricarboxylic acid cycle (Sulieman \& Schulze, 2010), or plant/bacteroid amino acid exchanges (Lodwig et al., 2003; Prell et al., 2009) have been implicated in these variations. The hypothesis that differential allocations of $\mathrm{C}$ metabolites may be a driver to pilot symbiotic organ development and function has been frequently suggested (Voisin et al., 2003 
and references therein), but only few studies have directly investigated this hypothesis (Jeudy et al., 2010). Indeed, as C metabolites fuel nodule functioning and development, $\mathrm{C}$ allocation and $\mathrm{N}_{2}$ fixation are always correlated and therefore, specific signaling associated to $\mathrm{C}$ allocation is difficult to discriminate from $\mathrm{N}$ signaling (Fig. 1). Nevertheless, $\mathrm{a}^{13} \mathrm{C}$ labeling experiment has shown that the systemic stimulation of nodule development in response to a local $\mathrm{N}$ deficit is correlated to very rapid changes of $\mathrm{C}$ metabolite allocation toward symbiotic organs before any measurable response on nodule development can be detected (Jeudy et al., 2010). This is in agreement with the hypothesis that plant $\mathrm{C}$ metabolites allocation to the bacteroid mediates at least a part of the plant $\mathrm{N}$ demand systemic response. According to this model, $\mathrm{C}$ allocation to nodules may be a driver allowing the plant to pilot the whole plant systemic preference toward $\mathrm{N}_{2}$ fixing efficient structures (i.e. with efficient partners) to the expense of the inefficient ones (i.e. with inefficient partners). However, how the plant perceive individual nodule $\mathrm{N}_{2}$ fixation efficiency and how the plant controls the differential C metabolite allocation toward $\mathrm{N}_{2}$ fixing efficient versus inefficient nodules is unknown and will deserve future investigations.

\section{Conclusions}

Symbiotic legumes are strategical for sustainable agriculture as well as a source of proteins for both human and animal food. Genetic selection during domestication improved their performances to agriculture needs (i.e. increased grain yields and protein content; Duc et al., 2015; Zhou et al., 2015), however the symbiotic interaction with rhizobia was rarely considered as a selection trait. Consequently, plant selection was even occasionally associated to a reduction of symbiotic capacities (Pérez-Jaramillo, Mendes, \& Raaijmakers, 2016; Weese, Heath, Dentinger, \& Lau, 2015). Inoculation strategies were then designed to bring in field more efficient $\mathrm{N}$-fixing rhizobia for different legume crops (Triplett \& Sadowsky, 1992). Nevertheless, inoculation strategies frequently failed because highly efficient selected strains were outcompeted by indigenous bacteria, which were highly competitive but poorly $\mathrm{N}_{2}$ fixing efficient with host plants (Triplett \& Sadowsky, 1992). Identifying rhizobium genetic determinants controlling AFN and CFN is therefore a key to allow selecting bacteria well adapted to inoculation strategies, i.e. both competitive and efficient. As the effect of biotic and abiotic soil environmental variations on AFN and CFN are 
almost unknown, a new frontier is to decipher and predict their impacts on early partner choice, in order to improve and stabilize inoculation strategies.

Legume genetic selection seems to have sometime reduced their wild capacities to interact with the rhizobial genetic diversity existing in natural soil populations (Bourion et al., 2018; Kim et al., 2014; Mutch \& Young, 2004), and in laboratory conditions legume productivity can be decreased when associated with a mixture of rhizobium genotypes compared to mono-inoculations (Barrett, Bever, Bissett, \& Thrall, 2015). Some domesticated soybean cultivars have an improved SNF when mono-inoculated with elite bacteria than wild soybeans (Muñoz et al., 2016). However, the gain is lower for the domesticated genotypes than for wild soybeans when a mixture of effective and ineffective rhizobial strains is used as inoculant (Kiers, Hutton, \& Denison, 2007). As legume genetic selection programs using single-strain inoculation tend to select specific traits associated to a specific bacterial strain, selection of new cultivars able to maintain high symbiotic performances upon multi-inoculation may be a new strategy to improve symbiotic capacities of legumes. The establishment of rhizobial core collections covering geographical, genomic, and symbiotic (i.e. nod genes ...) diversities, could be interesting tools to measure legume agronomic traits when challenged with multiple different partners.

Rhizobia are not obligate symbionts and can then be found as free-living bacteria in soils, meaning that their interaction with legumes is therefore only optional for their maintenance, survival and multiplication. Consequently, the dynamic of rhizobial populations cannot be explained only on the basis of their symbiotic interaction traits, and other selection pressures drive genetic population structures in soils. Notably, certain genotypes of rhizobia are able to colonize the endorhizosphere of non-legumes and to act potentially as Plant-Growth Promoting Rhizobacteria (PGPR; Tan, Radziah, Halimi, Khairuddin, \& Shamsuddin, 2015; Adnan et al., 2016; Santoyo, Moreno-Hagelsieb, del Carmen Orozco-Mosqueda, \& Glick, 2016; Vargas et al., 2017). In this case, the plant endorhizosphere likely plays the role of an ecological niche that favors bacterial proliferation, similarly as legume nodules. Therefore, soils contain a large set of rhizobia having heterogeneous behaviors with various plants, including non-legumes, and their soil symbiotic capacities are then very difficult to predict. New sequencing technologies, such as metagenomics and metabarcoding, have allowed to better describe dynamics of soil bacterial communities (Daniel, 2005; Taberlet, Coissac, Pompanon, Brochmann, \& Willerslev, 2012; Tringe et al., 2005), but these methods cannot predict symbiotic functions yet. 
However, the use of bacterial genetic markers, associated with symbiotic traits such as AFN, CFN and PIPP, should be a way for improving the prediction of soil symbiotic capacities.

\section{References}

Adnan, M., Shah, Z., Arif, M., Khan, M. J., Mian, I. A., Sharif, M., et al. (2016). Impact of rhizobial inoculum and inorganic fertilizers on nutrients (NPK) availability and uptake in wheat crop. Canadian Journal of Soil Science, 96(2), 169-176. https://doi.org/10.1139/ cjss-2016-0012.

Amarger, N. (1981). Competition for nodule formation between effective and ineffective strains of Rhizobium meliloti. Soil Biology and Biochemistry, 13(6), 475-480. https:// doi.org/10.1016/0038-0717(81)90037-7.

Bacanamwo, M., \& Harper, J. E. (1997). The feedback mechanism of nitrate inhibition of nitrogenase activity in soybean may involve asparagine and/or products of its metabolism. Physiologia Plantarum, 100(2), 371-377. https://doi.org/10.1111/j.1399_ 3054.1997.tb04795.x.

Bailly, X., Giuntini, E., Sexton, M. C., Lower, R. P., Harrison, P. W., Kumar, N., et al. (2011). Population genomics of Sinorhizobium medicae based on low-coverage sequencing of sympatric isolates. The ISME Journal, 5(11), 1722-1734. https:// doi.org/10.1038/ismej.2011.55.

Barrett, L. G., Bever, J. D., Bissett, A., \& Thrall, P. H. (2015). Partner diversity and identity impacts on plant productivity in Acacia-rhizobial interactions. Journal of Ecology, 103(1), 130-142. https://doi.org/10.1111/1365-2745.12336.

Bartsev, A. V., Deakin, W. J., Boukli, N. M., McAlvin, C. B., Stacey, G., Malnoë, P., et al. (2004). NopL, an effector protein of Rhizobium sp. NGR234, thwarts activation of plant defense reactions. Plant Physiology, 134(2), 871-879. https://doi.org/10.1104/ pp.103.031740.

Begum, A. A., Leibovitch, S., Migner, P., \& Zhang, F. (2001). Specific flavonoids induced nod gene expression and pre-activated nod genes of Rhizobium leguminosarum increased pea (Pisum sativum L.) and lentil (Lens culinaris L.) nodulation in controlled growth chamber environments. Journal of Experimental Botany, 52(360), 1537-1543. https://doi.org/10.1093/jexbot/52.360.1537.

Bernal, P., Llamas, M. A., \& Filloux, A. (2018). Type VI secretion systems in plant-associated bacteria. Environmental Microbiology, 20(1), 1-15. https://doi.org/10.1111/14622920.13956.

Borthakur, D., Barker, R. F., Latchford, J. W., Rossen, L., \& Johnston, A. W. B. (1988). Analysis of pss genes of Rhizobium leguminosarum required for exopolysaccharide synthesis and nodulation of peas: Their primary structure and their interaction with psi and other nodulation genes. Molecular and General Genetics MGG, 213(1), 155-162. https:// doi.org/10.1007/BF00333413.

Bouguyon, E., Gojon, A., \& Nacry, P. (2012). Nitrate sensing and signaling in plants. Seminars in Cell \& Developmental Biology, 23(6), 648-654. https://doi.org/10.1016/ j.semcdb.2012.01.004.

Bourion, V., Heulin-Gotty, K., Aubert, V., Tisseyre, P., Chabert-Martinello, M., Pervent, M., et al. (2018). Co-inoculation of a pea core-collection with diverse rhizobial strains shows competitiveness for nodulation and efficiency of nitrogen fixation are distinct traits in the interaction. Frontiers of Plant Science, 8. https://doi.org/10.3389/ fpls.2017.02249. 
Cooper, J. E. (2004). Multiple responses of rhizobia to flavonoids during legume root infection. In Incorporating advances in plant pathology: Vol. 41. Advances in botanical research (pp. 1-62). https://doi.org/10.1016/S0065-2296(04)41001-5.

Costa, T. R. D., Felisberto-Rodrigues, C., Meir, A., Prevost, M. S., Redzej, A., Trokter, M., et al. (2015). Secretion systems in Gram-negative bacteria : Structural and mechanistic insights. Nature Reviews Microbiology, 13(6), 343-359. https://doi.org/10.1038/ nrmicro3456.

Cregan, P. B., Keyser, H. H., \& Sadowsky, M. J. (1989). Soybean genotype restricting nodulation of a previously unrestricted serocluster 123 bradyrhizobia. Crop Science, 29(2), 307-312. https://doi.org/10.2135/cropsci1989.0011183X002900020015x.

Daniel, R. (2005). The metagenomics of soil. Nature Reviews Microbiology, 3(6), 470-478. https://doi.org/10.1038/nrmicro1160.

Daubech, B., Remigi, P., Doin de Moura, G., Marchetti, M., Pouzet, C., Auriac, M.-C., et al. (2017). Spatio-temporal control of mutualism in legumes helps spread symbiotic nitrogen fixation. ELife, 6. https://doi.org/10.7554/eLife.28683.

Davis, E. O., Evans, I. J., \& Johnston, A. W. (1988). Identification of nodX, a gene that allows Rhizobium leguminosarum biovar viciae strain TOM to nodulate Afghanistan peas. Molecular \& General Genetics: MGG, 212(3), 531-535.

Dénarié, J., Debellé, F., \& Promé, J. C. (1996). Rhizobium lipo-chitooligosaccharide nodulation factors: Signaling molecules mediating recognition and morphogenesis. Annual Review of Biochemistry, 65, 503-535. https://doi.org/10.1146/ annurev.bi.65.070196.002443.

Djordjevic, M. A., Schofield, P. R., \& Rolfe, B. G. (1985). Tn5 mutagenesis of Rhizobium trifolii host-specific nodulation genes result in mutants with altered host-range ability. Molecular and General Genetics MGG, 200(3), 463-471. https://doi.org/10.1007/ BF00425732.

Dowling, D. N., Stanley, J., \& Broughton, W. J. (1989). Competitive nodulation blocking of Afghanistan pea is determined by nodDABC and nodFE alleles in Rhizobium leguminosarum. Molecular and General Genetics MGG, 216(1), 170-174. https:// doi.org/10.1007/BF00332247.

Duc, G., Agrama, H., Bao, S., Berger, J., Bourion, V., Ron, A. M. D., et al. (2015). Breeding annual grain legumes for sustainable Agriculture: New methods to approach complex traits and target new cultivar ideotypes. Critical Reviews in Plant Sciences, 34(1-3), 381-411. https://doi.org/10.1080/07352689.2014.898469.

Economou, A., Hamilton, W. D., Johnston, A. W., \& Downie, J. A. (1990). The Rhizobium nodulation gene nodO encodes a $\mathrm{Ca} 2(+)$-binding protein that is exported without $\mathrm{N}$ terminal cleavage and is homologous to haemolysin and related proteins. The EMBO Journal, 9(2), 349-354. https://doi.org/10.1002/j.1460-2075.1990.tb08117.x.

Fellay, R., Hanin, M., Montorzi, G., Frey, J., Freiberg, C., Golinowski, W., et al. (1998). nodD2 of Rhizobium sp. NGR234 is involved in the repression of the nodABC operon. Molecular Microbiology, 27(5), 1039-1050.

Ferguson, B. J., Mens, C., Hastwell, A. H., Zhang, M., Su, H., Jones, C. H., et al. (2019). Legume nodulation: The host controls the party. Plant, Cell and Environment, 42(1), 41-51. https://doi.org/10.1111/pce.13348.

Fierer, N., \& Jackson, R. B. (2006). The diversity and biogeography of soil bacterial communities. Proceedings of the National Academy of Sciences of the United States of America, 103(3), 626-631. https://doi.org/10.1073/pnas.0507535103.

Firmin, J. L., Wilson, K. E., Carlson, R. W., Davies, A. E., \& Downie, J. A. (1993). Resistance to nodulation of $\mathrm{cv}$. Afghanistan peas is overcome by nodX, which mediates an $\mathrm{O}$-acetylation of the Rhizobium leguminosarum lipo-oligosaccharide nodulation factor. Molecular Microbiology, 10(2), 351-360. https://doi.org/10.1111/j.13652958.1993.tb01961.x. 
Firmin, J. L., Wilson, K. E., Rossen, L., \& Johnston, A. W. B. (1986). Flavonoid activation of nodulation genes in Rhizobium reversed by other compounds present in plants. Nature, 324(6092), 90. https://doi.org/10.1038/324090a0.

Fujita, H., Aoki, S., \& Kawaguchi, M. (2014). Evolutionary dynamics of nitrogen fixation in the legume-rhizobia symbiosis. PLoS One, 9(4), e93670. https://doi.org/10.1371/ journal.pone.0093670.

Gagnon, H., \& Ibrahim, R. K. (1998). Aldonic Acids : A novel family of nod gene inducers of Mesorhizobium loti, Rhizobium lupini, and Sinorhizobium meliloti. Molecular PlantMicrobe Interactions, 11(10), 988-998. https://doi.org/10.1094/MPMI.1998.11.10.988.

Gough, C., Cottret, L., Lefebvre, B., \& Bono, J.-J. (2018). Evolutionary history of plant LysM receptor proteins related to root endosymbiosis. Frontiers of Plant Science, 9. https://doi.org/10.3389/fpls.2018.00923.

Gourion, B., Berrabah, F., Ratet, P., \& Stacey, G. (2015). Rhizobium-legume symbioses : The crucial role of plant immunity. Trends in Plant Science, 20(3), 186-194. https:// doi.org/10.1016/j.tplants.2014.11.008.

Grillo, M. A., Stinchcombe, J. R., \& Heath, K. D. (2016). Nitrogen addition does not influence pre-infection partner choice in the legume-rhizobium symbiosis. American Journal of Botany, 103(10), 1763-1770. https://doi.org/10.3732/ajb.1600090.

Hogg, B., Davies, A. E., Wilson, K. E., Bisseling, T., \& Downie, J. A. (2002). Competitive nodulation blocking of $\mathrm{cv}$. Afghanistan pea is related to high levels of nodulation factors made by some strains of Rhizobium leguminosarum bv. Viciae. Molecular Plant-Microbe Interactions, 15(1), 60-68. https://doi.org/10.1094/MPMI.2002.15.1.60.

Hong, G. F., Burn, J. E., \& Johnston, A. W. (1987). Evidence that DNA involved in the expression of nodulation (nod) genes in Rhizobium binds to the product of the regulatory gene nodD. Nucleic Acids Research, 15(23), 9677-9690.

Huault, E., Laffont, C., Wen, J., Mysore, K. S., Ratet, P., Duc, G., et al. (2014). Local and systemic regulation of plant root system Architecture and symbiotic nodulation by a receptor-like kinase. PLoS Genetics, 10(12), e1004891. https://doi.org/10.1371/ journal.pgen.1004891.

Hunt, S., \& Layzell, D. B. (1993). Gas exchange of legume nodules and the regulation of nitrogenase activity. Annual Review of Plant Physiology and Plant Molecular Biology, 44(1), 483-511. https://doi.org/10.1146/annurev.pp.44.060193.002411.

Janczarek, M., Rachwał, K., Marzec, A., Grządziel, J., \& Palusińska-Szysz, M. (2015). Signal molecules and cell-surface components involved in early stages of the legume-rhizobium interactions. Applied Soil Ecology, 85, 94-113.

Jeudy, C., Ruffel, S., Freixes, S., Tillard, P., Santoni, A. L., Morel, S., et al. (2010). Adaptation of Medicago truncatula to nitrogen limitation is modulated via local and systemic nodule developmental responses. New Phytologist, 185(3), 817-828. https://doi.org/ 10.1111/j.1469-8137.2009.03103.x.

Jiménez-Guerrero, I., Acosta-Jurado, S., Del Cerro, P., Navarro-Gómez, P., LópezBaena, F. J., Ollero, F. J., et al. (2017). Transcriptomic studies of the effect of nod gene-inducing molecules in Rhizobia: Different weapons, one purpose. Genes, 9(1). https://doi.org/10.3390/genes9010001.

Kaiser, K., Wemheuer, B., Korolkow, V., Wemheuer, F., Nacke, H., Schöning, I., et al. (2016). Driving forces of soil bacterial community structure, diversity, and function in temperate grasslands and forests. Scientific Reports, 6, 33696. https://doi.org/10.1038/ srep33696.

Kaneko, T., Nakamura, Y., Sato, S., Minamisawa, K., Uchiumi, T., Sasamoto, S., et al. (2002). Complete genomic sequence of nitrogen-fixing symbiotic Bacterium Bradyrhizobium japonicum USDA110. DNA Research, 9(6), 189-197. https://doi.org/10.1093/ dnares/9.6.189. 
Kassaw, T., Bridges, W., \& Frugoli, J. (2015). Multiple autoregulation of nodulation (AON) signals identified through split root analysis of Medicago truncatula sunn and $\operatorname{rdn} 1$ mutants. Plants, 4(2), 209-224. https://doi.org/10.3390/plants4020209.

Kawaharada, Y., Kelly, S., Nielsen, M. W., Hjuler, C. T., Gysel, K., Muszyński, A., et al. (2015). Receptor-mediated exopolysaccharide perception controls bacterial infection. Nature, 523(7560), 308-312. https://doi.org/10.1038/nature14611.

Kazmierczak, T., Nagymihaly, M., Lamouche, F., BARRIERE, Q., Guefrachi, I., Alunni, B., et al. (2017). Specific host-responsive associations between Medicago truncatula accessions and Sinorhizobium strains. Molecular Plant-Microbe Interactions, 30(5), 399-409. https://doi.org/10.1094/MPMI-01-17-0009-R.

Kelly, S., Radutoiu, S., \& Stougaard, J. (2017). Legume LysM receptors mediate symbiotic and pathogenic signalling. Current Opinion in Plant Biology, 39, 152-158. https:// doi.org/10.1016/j.pbi.2017.06.013.

Keyser, H. H., \& Cregan, P. B. (1987). Nodulation and competition for nodulation of selected soybean genotypes among Bradyrhizobium japonicum serogroup 123 isolates. Applied and Environmental Microbiology, 53(11), 2631-2635.

Kiers, E. T., Hutton, M. G., \& Denison, R. F. (2007). Human selection and the relaxation of legume defences against ineffective rhizobia. Proceedings of the Royal Society B: Biological Sciences, 274(1629), 3119-3126. https://doi.org/10.1098/rspb.2007.1187.

Kiers, E. T., Rousseau, R. A., West, S. A., \& Denison, R. F. (2003). Host sanctions and the legume-rhizobium mutualism. Nature, 425(6953), 78-81. https://doi.org/10.1038/ nature01931.

Kim, D. H., Kaashyap, M., Rathore, A., Das, R. R., Parupalli, S., Upadhyaya, H. D., et al. (2014). Phylogenetic diversity of Mesorhizobium in chickpea. Journal of Biosciences, 39(3), $513-517$

Klümper, U., Riber, L., Dechesne, A., Sannazzarro, A., Hansen, L. H., Sørensen, S. J., et al. (2015). Broad host range plasmids can invade an unexpectedly diverse fraction of a soil bacterial community. The ISME Journal, 9(4), 934-945. https://doi.org/10.1038/ ismej.2014.191.

Kobayashi, H., Naciri-Graven, Y., Broughton, W. J., \& Perret, X. (2004). Flavonoids induce temporal shifts in gene-expression of nod-box controlled loci in Rhizobium sp. NGR234. Molecular Microbiology, 51(2), 335-347.

Kondorosi, E., Banfalvi, Z., \& Kondorosi, A. (1984). Physical and genetic analysis of a symbiotic region of Rhizobium meliloti: Identification of nodulation genes. Molecular and General Genetics MGG, 193(3), 445-452. https://doi.org/10.1007/BF00382082.

Kosslak, R. M., \& Bohlool, B. B. (1984). Suppression of nodule development of one side of a split-root system of soybeans caused by prior inoculation of the other side. Plant Physiology, 75(1), 125-130.

Kosslak, R. M., Bohlool, B. B., Dowdle, S., \& Sadowsky, M. J. (1983). Competition of Rhizobium japonicum strains in early stages of soybean nodulation. Applied and Environmental Microbiology, 46(4), 870-873.

Krause, A., Doerfel, A., \& Göttfert, M. (2002). Mutational and transcriptional analysis of the type III secretion system of Bradyrhizobium japonicum. Molecular Plant-Microbe Interactions: MPMI, 15(12), 1228-1235.

Krusell, L., Madsen, L. H., Sato, S., Aubert, G., Genua, A., Szczyglowski, K., et al. (2002). Shoot control of root development and nodulation is mediated by a receptor-like kinase. Nature, 420(6914), 422-426. https://doi.org/10.1038/nature01207.

Kumar, N., Lad, G., Giuntini, E., Kaye, M. E., Udomwong, P., Shamsani, N. J., et al. (2015). Bacterial genospecies that are not ecologically coherent : Population genomics of Rhizobium leguminosarum. Open Biology, 5(1), 140133. https://doi.org/10.1098/ rsob.140133. 
Laffont, C., Huault, E., Gautrat, P., Endre, G., Kalo, P., Bourion, V., et al. (2019). Independent regulation of symbiotic nodulation by the SUNN negative and CRA2 positive systemic pathways. Plant Physiology, 180(1), 559-570. https://doi.org/10.1104/ pp.18.01588.

Laguerre, G., Allard, M.-R., Revoy, F., \& Amarger, N. (1994). Rapid identification of rhizobia by restriction fragment length polymorphism analysis of PCR-amplified 16S rRNA genes. Applied and Environmental Microbiology, 60(1), 56-63.

Laguerre, G., Bardin, M., \& Amarger, N. (1993). Isolation from soil of symbiotic and nonsymbiotic Rhizobium leguminosarum by DNA hybridization. Canadian Journal of Microbiology, 39(12), 1142-1149. https://doi.org/10.1139/m93-172.

Laguerre, G., Heulin-Gotty, K., Brunel, B., Klonowska, A., Le Quéré, A., Tillard, P., et al. (2012). Local and systemic N signaling are involved in Medicago truncatula preference for the most efficient Sinorhizobium symbiotic partners. New Phytologist, 195(2), 437-449. https://doi.org/10.1111/j.1469-8137.2012.04159.x.

Laguerre, G., Louvrier, P., Allard, M.-R., \& Amarger, N. (2003). Compatibility of rhizobial genotypes within natural populations of Rhizobium leguminosarum biovar viciae for nodulation of host legumes. Applied and Environmental Microbiology, 69(4), 2276-2283.

Le Strange, K. K., Bender, G. L., Djordjevic, M. A., Rolfe, B. G., \& Redmond, J. W. (1990). The Rhizobium strain NGR234 nodD1 gene product responds to activation by the simple phenolic compounds vanillin and isovanillin present in wheat seedling extracts. Molecular Plant-Microbe Interactions, 3(4), 214-220.

Lejay, L., Gansel, X., Cerezo, M., Tillard, P., Müller, C., Krapp, A., et al. (2003). Regulation of root ion transporters by photosynthesis: Functional importance and relation with hexokinase. The Plant Cell, 15(9), 2218-2232. https://doi.org/10.1105/tpc.013516.

Lewis-Henderson, W. R., \& Djordjevic, M. A. (1991). NodT, a positively-acting cultivar specificity determinant controlling nodulation of Trifolium subterraneum by Rhizobium leguminosarum biovar trifolii. Plant Molecular Biology, 16(4), 515-526.

Li, X., Tong, W., Wang, L., Rahman, S. U., Wei, G., \& Tao, S. (2018). A novel strategy for detecting recent horizontal gene transfer and its application to Rhizobium strains. Frontiers in Microbiology, 9, 973. https://doi.org/10.3389/fmicb.2018.00973.

Lie, T. A. (1984). Host genes in Pisum sativum L. conferring resistance to European Rhizobium leguminosarum strains. Plant and Soil, 82(3), 415-425. https://doi.org/10.1007/ BF02184279.

Lodwig, E. M., Hosie, A. H. F., Bourdès, A., Findlay, K., Allaway, D., Karunakaran, R., et al. (2003). Amino-acid cycling drives nitrogen fixation in the legume-rhizobium symbiosis. Nature, 422(6933), 722-726. https://doi.org/10.1038/nature01527.

Madsen, E. B., Antolín-Llovera, M., Grossmann, C., Ye, J., Vieweg, S., Broghammer, A., et al. (2011). Autophosphorylation is essential for the in vivo function of the Lotus japonicus Nod factor receptor 1 and receptor-mediated signalling in cooperation with Nod factor receptor 5. The Plant Journal, 65(3), 404-417. https://doi.org/10.1111/j.1365313X.2010.04431.x.

Maj, D., Wielbo, J., Marek-Kozaczuk, M., \& Skorupska, A. (2010). Response to flavonoids as a factor influencing competitiveness and symbiotic activity of Rhizobium leguminosarum. Microbiological Research, 165(1), 50-60. https://doi.org/10.1016/ j.micres.2008.06.002.

Marco, D. E., Carbajal, J. P., Cannas, S., Pérez-Arnedo, R., Hidalgo-Perea, A., Olivares, J., et al. (2009). An experimental and modelling exploration of the host-sanction hypothesis in legume-rhizobia mutualism. Journal of Theoretical Biology, 259(3), 423-433. https:// doi.org/10.1016/j.jtbi.2009.03.033.

McAnulla, C., Edwards, A., Sanchez-Contreras, M., Sawers, R. G., \& Downie, J. A. (2007). Quorum-sensing-regulated transcriptional initiation of plasmid transfer and replication 
genes in Rhizobium leguminosarum biovar viciae. Microbiology (Reading, England), 153(Pt 7), 2074-2082. https://doi.org/10.1099/mic.0.2007/007153-0.

Mergaert, P., Montagu, M. V., \& Holsters, M. (1997). Molecular mechanisms of Nod factor diversity. Molecular Microbiology, 25(5), 811-817. https://doi.org/10.1111/j.13652958.1997.mmi526.x.

Miwa, H., \& Okazaki, S. (2017). How effectors promote beneficial interactions. Current Opinion in Plant Biology, 38, 148-154. https://doi.org/10.1016/j.pbi.2017.05.011.

Moawad, H. A., Ellis, W. R., \& Schmidt, E. L. (1984). Rhizosphere response as a factor in competition among three serogroups of indigenous Rhizobium japonicum for nodulation of field-grown soybeans. Applied and Environmental Microbiology, 47(4), 607-612.

Muñoz, N., Qi, X., Li, M.-W., Xie, M., Gao, Y., Cheung, M.-Y., et al. (2016). Data from : Improvement in nitrogen fixation capacity could be part of the domestication process in soybean. Heredity. https://doi.org/10.5061/dryad.vp6fs.

Mutch, L. A., \& Young, J. P. W. (2004). Diversity and specificity of Rhizobium leguminosarum biovar viciae on wild and cultivated legumes. Molecular Ecology, 13(8), 2435-2444. https://doi.org/10.1111/j.1365-294X.2004.02259.x.

Naamala, J., Jaiswal, S. K., \& Dakora, F. D. (2016). Antibiotics resistance in Rhizobium: Type, process, mechanism and benefit for agriculture. Current Microbiology, 72(6), 804-816. https://doi.org/10.1007/s00284-016-1005-0.

Okazaki, S., Kaneko, T., Sato, S., \& Saeki, K. (2013). Hijacking of leguminous nodulation signaling by the rhizobial type III secretion system. Proceedings of the National Academy of Sciences of the United States of America, 110(42), 17131-17136. https://doi.org/10.1073/ pnas.1302360110.

Oldroyd, G. E. D., Murray, J. D., Poole, P. S., \& Downie, J. A. (2011). The rules of engagement in the legume-rhizobial symbiosis. Annual Review of Genetics, 45, 119-144. https:// doi.org/10.1146/annurev-genet-110410-132549.

Olsson, J. E., Nakao, P., Bohlool, B. B., \& Gresshoff, P. M. (1989). Lack of systemic suppression of nodulation in split root systems of supernodulating soybean (Glycine max [L.] Merr.) mutants. Plant Physiology, 90(4), 1347-1352. https://doi.org/10.1104/ pp.90.4.1347.

Oono, R., Anderson, C. G., \& Denison, R. F. (2011). Failure to fix nitrogen by non-reproductive symbiotic rhizobia triggers host sanctions that reduce fitness of their reproductive clonemates. Proceedings. Biological Sciences, 278(1718), 2698-2703. https://doi.org/ 10.1098/rspb.2010.2193.

Oono, R., \& Denison, R. F. (2010). Comparing symbiotic efficiency between swollen versus nonswollen rhizobial Bacteroids1[C][W][OA]. Plant Physiology, 154(3), 1541-1548. https://doi.org/10.1104/pp.110.163436.

Oono, R., Denison, R. F., \& Kiers, E. T. (2009). Controlling the reproductive fate of rhizobia : How universal are legume sanctions? The New Phytologist, 183(4), 967-979. https://doi.org/10.1111/j.1469-8137.2009.02941.x.

Papenfort, K., \& Bassler, B. L. (2016). Quorum sensing signal-response systems in Gramnegative bacteria. Nature Reviews Microbiology, 14(9), 576-588. https://doi.org/ 10.1038/nrmicro.2016.89.

Parsons, R., Stanforth, A., Raven, J. A., \& Sprent, J. I. (1993). Nodule growth and activity may be regulated by a feedback mechanism involving phloem nitrogen ${ }^{\star}$. Plant, Cell and Environment, 16(2), 125-136. https://doi.org/10.1111/j.1365-3040.1993.tb00854.x.

Patrick, H. N., \& Lowther, W. L. (1992). Response of Lotus corniculatus to inoculation and pelleting on a range of Otago tussock grassland environments. Proceedings of the New Zealand Grassland Association, (54), 105-109.

Peck, M. C., Fisher, R. F., \& Long, S. R. (2006). Diverse flavonoids stimulate NodD1 binding to nod gene promoters in Sinorhizobium meliloti. Journal of Bacteriology, 188(15), 5417-5427. https://doi.org/10.1128/JB.00376-06. 
Pérez-Jaramillo, J. E., Mendes, R., \& Raaijmakers, J. M. (2016). Impact of plant domestication on rhizosphere microbiome assembly and functions. Plant Molecular Biology, 90, 635-644. https://doi.org/10.1007/s11103-015-0337-7.

Prell, J., White, J. P., Bourdes, A., Bunnewell, S., Bongaerts, R. J., \& Poole, P. S. (2009). Legumes regulate Rhizobium bacteroid development and persistence by the supply of branched-chain amino acids. Proceedings of the National Academy of Sciences of the United States of America, 106(30), 12477-12482. https://doi.org/10.1073/pnas.0903653106.

Radutoiu, S., Madsen, L. H., Madsen, E. B., Jurkiewicz, A., Fukai, E., Quistgaard, E. M., et al. (2007). LysM domains mediate lipochitin-oligosaccharide recognition and Nfr genes extend the symbiotic host range. The EMBO Journal, 26(17), 3923-3935. https://doi.org/10.1038/sj.emboj.7601826.

Revellin, C., Pinochet, X., Beauclair, P., \& Catroux, G. (1996). Influence of soil properties and soya bean cropping history on the Bradyrhizobium japonicum population in some French soils. European Journal of Soil Science, 47(4), 505-510. https://doi.org/10.1111/ j.1365-2389.1996.tb01850.x.

Rivilla, R., Sutton, J. M., \& Downie, J. A. (1995). Rhizobium leguminosarum NodT is related to a family of outer-membrane transport proteins that includes TolC, PrtF, CyaE and AprF. Gene, 161(1), 27-31.

Robleto, E. A., Scupham, A. J., \& Triplett, E. W. (1997). Trifolitoxin production in Rhizobium etli strain CE3 increases competitiveness for rhizosphere colonization and root nodulation of Phaseolus vulgaris in soil. Molecular Plant-Microbe Interactions, 10(2), 228-233. https://doi.org/10.1094/MPMI.1997.10.2.228.

Rogers, A., Ainsworth, E. A., \& Leakey, A. D. B. (2009). Will elevated carbon dioxide concentration amplify the benefits of nitrogen fixation in legumes? Plant Physiology, 151(3), 1009-1016. https://doi.org/10.1104/pp.109.144113.

Rogers, A., Gibon, Y., Stitt, M., Morgan, P. B., Bernacchi, C. J., Ort, D. R., et al. (2006). Increased $\mathrm{C}$ availability at elevated carbon dioxide concentration improves $\mathrm{N}$ assimilation in a legume. Plant, Cell and Environment, 29(8), 1651-1658.

Rousk, J., Bååth, E., Brookes, P. C., Lauber, C. L., Lozupone, C., Caporaso, J. G., et al. (2010). Soil bacterial and fungal communities across a $\mathrm{pH}$ gradient in an arable soil. The ISME Journal, 4(10), 1340-1351. https://doi.org/10.1038/ismej.2010.58.

Ruffel, S., Freixes, S., Balzergue, S., Tillard, P., Jeudy, C., Martin-Magniette, M. L., et al. (2008). Systemic signaling of the plant nitrogen status triggers specific transcriptome responses depending on the nitrogen source in Medicago truncatula. Plant Physiology, 146(4), 2020-2035. https://doi.org/10.1104/pp.107.115667.

Ruffel, S., Gojon, A., \& Lejay, L. (2014). Signal interactions in the regulation of root nitrate uptake. Journal of Experimental Botany, 65(19), 5509-5517. https://doi.org/10.1093/ jxb/eru321.

Russo, D. M., Williams, A., Edwards, A., Posadas, D. M., Finnie, C., Dankert, M., et al. (2006). Proteins exported via the PrsD-PrsE type I secretion system and the acidic exopolysaccharide are involved in biofilm formation by Rhizobium leguminosarum. Journal of Bacteriology, 188(12), 4474-4486. https://doi.org/10.1128/JB.00246-06.

Santoyo, G., Moreno-Hagelsieb, G., del Carmen Orozco-Mosqueda, M., \& Glick, B. R. (2016). Plant growth-promoting bacterial endophytes. Microbiological Research, 183, 92-99. https://doi.org/10.1016/j.micres.2015.11.008.

Soucy, S. M., Huang, J., \& Gogarten, J. P. (2015). Horizontal gene transfer : Building the web of life. Nature Reviews Genetics, 16(8), 472-482. https://doi.org/10.1038/nrg3962.

Spaink, H. P., Bloemberg, G. V., Van Brussel, A. A. N., Lugtenberg, B. J. J., van der Drift, K. M. G. M., Haverkamp, J., \& Thomas-Oates, J. E. (1995). Molecular Plant-Microbe Interactions, 8, 155-164. 
Spaink, H. P., Okker, R. J. H., Wijffelman, C. A., Pees, E., \& Lugtenberg, B. J. J. (1987). Promoters in the nodulation region of the Rhizobium leguminosarum Sym plasmid pRL1JI. Plant Molecular Biology, 9(1), 27-39. https://doi.org/10.1007/BF00017984.

Staehelin, C., \& Krishnan, H. B. (2015). Nodulation outer proteins : Double-edged swords of symbiotic rhizobia. Biochemical Journal, 470(3), 263-274. https://doi.org/10.1042/ BJ20150518.

Streeter, J., \& Wong, P. P. (1988). Inhibition of legume nodule formation and N2 fixation by nitrate. Critical Reviews in Plant Sciences, 7(1), 1-23. https://doi.org/10.1080/ 07352688809382257.

Sulieman, S., Fischinger, S. A., Gresshoff, P. M., \& Schulze, J. (2010). Asparagine as a major factor in the $\mathrm{N}$-feedback regulation of N2 fixation in Medicago truncatula. Physiologia Plantarum, 140(1), 21-31. https://doi.org/10.1111/j.1399-3054.2010.01380.x.

Sulieman, S., \& Schulze, J. (2010). Phloem-derived $\gamma$-aminobutyric acid (GABA) is involved in upregulating nodule N2 fixation efficiency in the model legume Medicago truncatula. Plant, Cell and Environment, 33(12), 2162-2172. https://doi.org/10.1111/j.13653040.2010.02214.x.

Sulima, A. S., Zhukov, V. A., Afonin, A. A., Zhernakov, A. I., Tikhonovich, I. A., \& Lutova, L. A. (2017). Selection signatures in the first exon of paralogous receptor kinase genes from the Sym 2 region of the Pisum sativum L. Genome. Frontiers of Plant Science, 8. https://doi.org/10.3389/fpls.2017.01957.

Sullivan, J. T., Eardly, B. D., van Berkum, P., \& Ronson, C. W. (1996). Four unnamed species of nonsymbiotic rhizobia isolated from the rhizosphere of Lotus corniculatus. Applied and Environmental Microbiology, 62(8), 2818-2825.

Sullivan, J. T., Patrick, H. N., Lowther, W. L., Scott, D. B., \& Ronson, C. W. (1995). Nodulating strains of Rhizobium loti arise through chromosomal symbiotic gene transfer in the environment. Proceedings of the National Academy of Sciences of the United States of America, 92(19), 8985-8989.

Sun, J., Cardoza, V., Mitchell, D. M., Bright, L., Oldroyd, G., \& Harris, J. M. (2006). Crosstalk between jasmonic acid, ethylene and Nod factor signaling allows integration of diverse inputs for regulation of nodulation. The Plant Journal, 46(6), 961-970. https:// doi.org/10.1111/j.1365-313X.2006.02751.x.

Surin, B. P., Watson, J. M., Hamilton, W. D. O., Economou, A., \& Downie, J. A. (1990). Molecular characterization of the nodulation gene, nodT, from two biovars of Rhizobium leguminosarum. Molecular Microbiology, 4(2), 245-252. https://doi.org/10.1111/ j.1365-2958.1990.tb00591.x.

Taberlet, P., Coissac, E., Pompanon, F., Brochmann, C., \& Willerslev, E. (2012). Towards next-generation biodiversity assessment using DNA metabarcoding. Molecular Ecology, 21(8), 2045-2050. https://doi.org/10.1111/j.1365-294X.2012.05470.x.

Tan, K. Z., Radziah, O., Halimi, M. S., Khairuddin, A. R., \& Shamsuddin, Z. H. (2015). Assessment of plant growth-promoting rhizobacteria (PGPR) and rhizobia as multi-strain biofertilizer on growth and N2 fixation of rice plant. Australian Journal of Crop Science, 9(12), 1257.

Terpolilli, J. J., O’Hara, G. W., Tiwari, R. P., Dilworth, M. J., \& Howieson, J. G. (2008). The model legume Medicago truncatula A17 is poorly matched for N2 fixation with the sequenced microsymbiont Sinorhizobium meliloti 1021. New Phytologist, 179(1), 62-66. https://doi.org/10.1111/j.1469-8137.2008.02464.x.

Tringe, S. G., Mering, C. von, Kobayashi, A., Salamov, A. A., Chen, K., Chang, H. W., et al. (2005). Comparative metagenomics of Microbial communities. Science, 308(5721), 554-557. https://doi.org/10.1126/science.1107851.

Triplett, E. W., \& Barta, T. M. (1987). Trifolitoxin production and nodulation are necessary for the expression of superior nodulation competitiveness by Rhizobium leguminosarum bv. Trifolii strain T24 on clover 1. Plant Physiology, 85(2), 335-342. 
Triplett, E. W., \& Sadowsky, M. J. (1992). Genetics of competition for nodulation of legumes. Annual Review of Microbiology, 46, 399-428. https://doi.org/10.1146/ annurev.mi.46.100192.002151.

Vargas, L. K., Volpiano, C. G., Lisboa, B. B., Giongo, A., Beneduzi, A., \& Passaglia, L. M. P. (2017). Potential of rhizobia as plant growth-promoting rhizobacteria. In A. Zaidi, M. S. Khan, \& J. Musarrat (Eds.), Microbes for legume improvement (pp. 153-174). https://doi.org/10.1007/978-3-319-59174-2_7.

Voisin, A. S., Salon, C., Jeudy, C., \& Warembourg, F. R. (2003). Symbiotic N2 fixation activity in relation to $\mathrm{C}$ economy of Pisum sativum L. as a function of plant phenology. Journal of Experimental Botany, 54(393), 2733-2744. https://doi.org/ 10.1093/jxb/erg290.

Wakelin, S., Tillard, G., van Ham, R., Ballard, R., Farquharson, E., Gerard, E., et al. (2018). High spatial variation in population size and symbiotic performance of Rhizobium leguminosarum bv. Trifolii with white clover in New Zealand pasture soils. PLoS One, 13(2), e0192607. https://doi.org/10.1371/journal.pone.0192607.

Weese, D. J., Heath, K. D., Dentinger, B. T. M., \& Lau, J. A. (2015). Long-term nitrogen addition causes the evolution of less-cooperative mutualists. Evolution, 69(3), 631-642. https://doi.org/10.1111/evo.12594.

Westhoek, A., Field, E., Rehling, F., Mulley, G., Webb, I., Poole, P. S., et al. (2017). Policing the legume-rhizobium symbiosis: A critical test of partner choice. Scientific Reports, 7(1), 1-10. https://doi.org/10.1038/s41598-017-01634-2.

Winarno, R., \& Lie, T. A. (1979). Competition between Rhizobium strains in nodule formation : Interaction between nodulating and non-nodulating strains. Plant and Soil, 51(1), 135-142. https://doi.org/10.1007/BF02205933.

Xin, D.-W., Liao, S., Xie, Z.-P., Hann, D. R., Steinle, L., Boller, T., et al. (2012). Functional analysis of NopM, a novel E3 ubiquitin ligase (NEL) domain effector of Rhizobium sp. Strain NGR234. PLoS Pathogens, 8(5), e1002707. https://doi.org/ 10.1371/journal.ppat.1002707.

Yang, S., Tang, F., Gao, M., Krishnan, H. B., \& Zhu, H. (2010). R gene-controlled host specificity in the legume-rhizobia symbiosis. Proceedings of the National Academy of Sciences of the United States of America, 107(43), 18735-18740. https://doi.org/10.1073/ pnas.1011957107.

Young, J. P. W., Crossman, L. C., Johnston, A. W., Thomson, N. R., Ghazoui, Z. F., Hull, K. H., et al. (2006). The genome of Rhizobium leguminosarum has recognizable core and accessory components. Genome Biology, 7(4), R34. https://doi.org/10.1186/ $\mathrm{gb}-2006-7-4-\mathrm{r} 34$.

Young, J. P. W., \& Wexler, M. (1988). Sym plasmid and chromosomal genotypes are correlated in field populations of Rhizobium leguminosarum. Microbiology, 134(10), 2731-2739. https://doi.org/10.1099/00221287-134-10-2731.

Zézé, A., Mutch, L. A., \& Young, J. P. (2001). Direct amplification of nodD from community DNA reveals the genetic diversity of Rhizobium leguminosarum in soil. Environmental Microbiology, 3(6), 363-370.

Zhou, Z., Jiang, Y., Wang, Z., Gou, Z., Lyu, J., Li, W., et al. (2015). Resequencing 302 wild and cultivated accessions identifies genes related to domestication and improvement in soybean. Nature Biotechnology, 33(4), 408-414. https://doi.org/10.1038/nbt.3096. 